UDC 63.82

\title{
THE MAIN DIRECTIONS OF ECONOMIC DEVELOPMENT AND ASSESSMENT OF INTEGRATION EFFECTS IN THE EURASIAN ECONOMIC UNION IN THE CONDITIONS OF GLOBAL CHALLENGES
}

\author{
${ }^{1}$ Aroupova N. R., ${ }^{2}$ Abaidullayeva M.M., ${ }^{3}$ Arupova N.A.
}

${ }^{1} \mathrm{Ph} . \mathrm{D}$, associate professor, Moscow State Institute of International

Relations (University) Ministry of Foreign Affairs of Russia, Russia, Moscow, e-mail: n.aroupova@mail.ru ${ }^{2} \mathrm{Ph} . \mathrm{D}$, Institute of World Economy and International Relations, associate professor «Turan» University, Almaty, Kazakhstan, e-mail: madina09@mail.ru

${ }^{3}$ Doctoral student of «Turan» University, Almaty, Kazakhstan, Almaty e-mail: nargiza-05@mail.ru

\begin{abstract}
This article considers the strategic directions of economic development of the member states of the Eurasian Economic Union, based on available resources and objective opportunities for their joint effective use. With all the turbulence and uncertainty that exist today in the world economy, the definition of the main directions for the coordination of economic policies looks extremely important and timely. In general, by 2030, the results of the economic development of the EAEU have to show the world competitiveness of the integration association. In the 2030s, the economic development of the EAEU would be possible to overcome the competitive advantages of integration integration. The Customs Union of Kazakhstan, Belarus and Russia is a logical breakthrough from the Eurasian Economic Community. Established in 2000 in the format of Belarus, Kazakhstan, Kyrgyzstan, Russia and Tadjikistan - a momentous moment in the practice of the Eurasian integration. For all 11 years EurAsEC has been shaped by the mechanism of differentiation of mechanisms in the integration process. By the way, they do not just become intergovernmental, but also by initiative entrepreneurs, educators, education and culture, NGOs, and youth. With the help of the global financial and economic crisis, the creation of the Eurasian bank was undermined by the anti crisis. Kazakhstan considers Eurasia Union as an open project. Его нельзя представить без международному общественности, например, с Евросоюзом, with other convergence. Astana observes that the Euroasian Soyuz propiska is a defensive part of the Chinese definition of economic expansion.
\end{abstract}

Key words: EAEU, integration effects, Eurasian integration.

\section{Жаһандық сын-қатері жағдайында еуразиялық экономикалық одақтағы экономикалық дамудың негізгі бағыттары және интеграциялық әсерлердің бағалауы}

\author{
${ }^{1}$ Арупова Н.Р., ${ }^{2}$ Абайдуллаева М. М., ${ }^{3}$ Арупова Н.А.
}

${ }^{1} \mathrm{Ph} . \mathrm{D}$, Ресей Федерациясының Сыртқы істер министрлігінің Мәскеу

мемлекеттік халықаралық қатынастар институтының доценті, Мәскеу, Pесей, e-mail: n.aroupova@mail.ru

${ }^{2} \mathrm{Ph} . \mathrm{D}$, Әлемдік экономика және халықаралық қатынастар институты, «Тұран» университетінің доценті, Алматы, Қазақстан, e-mail: madina09@mail.ru

««Тұран» университетінің докторанті, Алматы, Қазақстан, e-mail: nargiza-05@mail.ru

Аңдатпа. Бұл мақалада Еуразиялық Экономикалық Одақ мүше мемлекеттердің экономикалық дамуының стратегиялық бағыттарын қарастырады. Олар қолда бар ресурстарға және оларды бірлескен тиімді пайдаланудың объективті мүмкіндіктеріне негізделген. Әлемдік экономикадағы бар кезде барлық турбуленттілік пен белгісіздікпен экономикалық саясатты үйлестірудің негізгі бағыттарын айқындау өте маңызды және уақытылы көрінеді. Жалпы, 2030 жылға қарай ЕАЭО-тың экономикалық дамуының нәтижелері интеграциялық бірлестіктің әлемдік бәсекеге қабілеттілігін көрсетуі керек. Еуразиялық экономикалық одақтың экономикалық дамуының қорытындысы бойынша интеграциялық интеграцияның бәсекеге қабілеттілігін арттыруға бағытталған 
бүкіл әлемде 2030 жылдан бастап жүзеге асырылады. Таможенный одақ Қазақстан, Беларусия және Ресейдің Еуразиялық экономикалық қоғамдастығына қисынды кірді. Сіз 2000 жылы елімізде қалыптасқан жылы - Беларусь, Қазақстан, Қырғызстан, Ресей және Тәжікстан - еуразиялық интеграцияда тәжірибе жинақтап тұрды. ЕурАзЭС шеңберіндегі 11 жыл бойы интеграциялық процестің айырымдық өлшемдері бойынша бөлінген құрылымның механизмін құрастырды. Олар тек мемлекеттік деңгейде ғана емес, сонымен бірге бизнес-инициативалармен, науқандар, білім беру және мәдениет, НПО, жасөспірімдер. Жаһандық қаржы-экономикалық дағдарыстың Еуразиялық банктің дамуына және антикризистік фонда қалыптасуына мүмкіндік туғызды. Қазақстан Еуразиялық Одақтың ашық жобасын бағалайды. Егжей-тегжейлі байланыстың болмауы, мысалы, Еуросоюз, басқа бірлестіктер. Астана емес деп санайды, бұл Еуразиялық Союзға Қытайдың экономикалық экспансиясы деп аталады.

Түйін сөздер: ЕАЭО, интеграциялық әсерлері, еуразиялық интеграция.

\title{
Основные направления экономического развития и оценка интеграционных эффектов в Евразийском экономическом союзе в условиях глобальных вызовов
}

\author{
${ }^{1}$ Арупова Н.Р., ${ }^{2}$ Абайдуллаева М. М., ${ }^{3}$ Арупова Н.А. \\ ${ }^{1} \mathrm{Ph} . \mathrm{D}$, доцент , Московского государственного института международных отношений МИД РФ, \\ Москва, Россия, e-mail: n.aroupova@mail.ru \\ ${ }^{2} \mathrm{Ph} . \mathrm{D}$, Институт мировой экономики и международных отношений, доцент университета «Туран», \\ Алматы, Казахстан, e-mail: madina09@mail.ru \\ 3Докторант университета «Туран», Алматы, Казахстан, e-mail: nargiza-05@mail.ru
}

\begin{abstract}
Аннотация. В данной статье рассматриваются стратегические направления экономического развития государств-членов Евразийского экономического союза, основанные на имеющихся ресурсах и объективных возможностях их совместного эффективного использования. При всей турбулентности и неопределенности, которые существуют сегодня в мировой экономике, определение основных направлений координации экономических политик выглядит крайне важным и своевременным. В статье отмечается, что в целом к 2030 году результаты экономического развития ЕАЭС должны продемонстрировать мировую конкурентоспособность интеграционного объединения. Таможенный союз Казахстана, Беларуси и России логично вырос из Евразийского экономического сообщества. Его создание в 2000 году в формате пяти стран - Беларуси, Казахстана, Кыргызстана, России и Таджикистана - стало переломным моментом в практике евразийской интеграции. Всего за 11 лет в рамках ЕврАзЭСа сформировалась разветвленная структура механизмов по различным измерениям интеграционного процесса. Причем они учреждаются не только на межгосударственном уровне, но и снизу по инициативе бизнесменов, деятелей науки, образования и культуры, НПО, молодежи. Своевременным с учетом глобального финансово-экономического кризиса было создание Евразийского банка развития и Антикризисного фонда. Казахстан рассматривает Евразийский Союз как открытый проект. Его нельзя представить без широкого взаимодействия, например, с Евросоюзом, другими объединениями. Астана не считает, что Евразийский Союз призван стать защитой от так называемой китайской экономической экспансии.
\end{abstract}

Ключевые слова: ЕАЭС, интеграционные эффекты, евразийская интеграция.

Introduction. The formation of the Eurasian Economic Union was a consequence of the search for a format and directions for an equally beneficial cooperation.

1 On March 29, 1994 in the walls of Moscow State University named after Lomonosov M.V. the President of the Republic of Kazakhstan Nazarbayev N.A. came up with an idea of creation of new integration association - Eurasian Economic Union which could "function freely only on the principles of equality, voluntariness, consideration of pragmatic interests and mutual benefit for each participating country" (Arupov A.A., Abaidullayeva M.M., Raitskaya L.K., Aroupova N.R., 2015.)

According to Nursultan Abishevich, the concept of association already gives a chance to our people to build a new type of the multilateral interstate relations based on important points which are close and clear to all citizens of the CIS countries, such as general history and close interrelation of cultures, mutual economic attraction and proximity of human aspirations.

In spite of the fact that this idea hasn't been understood and underestimated by most of politicians of that time in the CIS, today became relevant and widely demanded not only in a business community, but also at the public and humanitarian level. Integration processes in the Eurasian space are increasingly gaining momentum. Moreover, many joint platforms that strengthen Eurasian integration are already functioning actively and successfully: Eurasian Development Bank, Eurasian Economic 
Club of Scientists, Eurasian Business Council, Eurasian Media Forum, Eurasian Association of Universities and many others.

International practice shows that any interstate association is experiencing different stages in its development and is complemented by new forms of cooperation

Literature review. Research of the main trends of the digital economy dedicated to the works by: Arupov A.A., Abaidullayeva M.M., Raitskaya L.K., Aroupova N.R, Vinokurov E., Tsukarev T., Gnidchenko A., Salnikov V. Golovnin M., Zakharov A., Ushkalova D. Sultanov B. K., Uralov S.

Material and Methods. In the conditions of the modern economic reality which is characterized by tendencies of globalization and regionalization, member states of EAEU have taken the path of uniting the potentials of national economies for their sustainable development.

The presence of a serious resource base, industrial, scientific and technical potential creates opportunities for the extensive integration agenda, which allows to expand the list of economic areas and market niches in the long term, in which the EAEU is an important player in the world arena.

Results and Discussion. According to the official website of the Eurasian Economic Commission, today the EAEU has a huge economic potential, in particular (Table 1):

Table 1 - Economic potential of EAEU

\begin{tabular}{|c|c|c|c|}
\hline Potential & The place in the world & Indicator & World share \\
\hline Gas production & 2 & 682,6 billion $\mathrm{m}^{3}$ & $18,4 \%$ \\
\hline Oil production & 1 & 607,5 million tons & $14,6 \%$ \\
\hline Coal mining & 6 & 261 million tons & $5,8 \%$ \\
\hline Electricity generation & 4 & 1210,2 billion $\mathrm{kWh}$ & $5,1 \%$ \\
\hline $\begin{array}{c}\text { Metallurgical production: } \\
-\quad \text { cast iron } \\
-\quad \text { steel }\end{array}$ & $\begin{array}{l}3 \\
5\end{array}$ & $\begin{array}{l}54,6 \text { million tons } \\
76,9 \text { million tons }\end{array}$ & $\begin{array}{l}4,5 \% \\
4,5 \%\end{array}$ \\
\hline Production of mineral fertilizers & 2 & 27349 thousand tons & $10,8 \%$ \\
\hline Agricultural production: & 5 & $\$ 144,1$ billion. & $5,5 \%$ \\
\hline $\begin{array}{l}\text { Gross collecting grain and leguminous } \\
\text { crops }\end{array}$ & 5 & 134 million tons & $5,5 \%$ \\
\hline Production of milk & 3 & 44 million tons & $7 \%$ \\
\hline Road infrastructure & 5 & 1605,9 thousand $\mathrm{km}$ & $2,5 \%$ \\
\hline Railway infrastructure & 2 & 107 thousand $\mathrm{km}$ & $7,8 \%$ \\
\hline
\end{tabular}

The main directions of economic development of the Eurasian Economic Union (EAEU) till 2030, accepted by the decision of the Higher Eurasian Economic Council on October 16, 2015, are presented below:

1. Ensuring macroeconomic stability:

- improvement of measures, tools and mechanisms of ensuring macroeconomic stability;

- increase in technological level;

- diversification of production and export;

- maintenance of a steady condition of balances of payments; Union.

- decrease in external debt of the states of the
2. Creation of conditions for growth of business activity and investment attractiveness:

- reduction of exemptions, restrictions and barriers to the free movement of goods, services, capital and labor;

- development of the competition in the crossborder markets of the Union;

- creation of legal, institutional and financial conditions;

- maintenance of a steady condition of balances of payments; level.

- saving external debt at a consistently low 
3. Innovative development and modernization of economy:

- increase in level of scientific and technical potential;

- development of the knowledge-intensive branches;

- increase in a share of hi-tech export.

4. Ensuring availability of financial resources and formation of the effective financial market of the Union:

- harmonization of the national legislation and practice of its application;

- creation by 2025 of supranational regulator in the financial markets;

- carrying out the coordinated currency policy;

- improvement of regulation of securities market;

- formation of the integrated exchange space;

- solution of problems of crediting of the enterprises of the real sector of economy;

- decrease in level of the state participation.

5. Infrastructure development and realization of transit potential:

- harmonization of the legislation in the sphere of transport;

- stimulation of creation of uniform transport space and common market of transport services;

- integration into the world transport system;

- expansion of participation in large international transport projects;

- improvement of quality of transport and logistics services;

- improvement of customs, boundary procedures and procedures of transport control.

6. Development of personnel potential in the conditions of transition to innovative economy:

- creation of legal, institutional and financial conditions;

- development of hi-tech sectors of economy;

- decrease in deficiency of a highly skilled manpower;

- development of the system of monitoring of the movement of a manpower;

- cooperation on ensuring effective functioning of labor market.

7. Cooperation in resource-saving and increase in energy efficiency:

- development of uniform requirements and standards to the imported and released production in territories of the states;

- formation of the uniform scientific platform for development and commercialization of energy efficient technologies;

- construction of facilities of power infrastructure with the minimum negative consequences for the environment;
- production (import from the third countries) energy saving production technologies and stimulation of their application;

- development of low-power-intensive sectors of economy, renewable and alternative energy sources;

- expansion of participation of the states in implementation of projects in the sphere of nuclear power.

8. Regional development (interregional and border cooperation):

- cooperation of border territories on a multilateral basis;

- exchange of experience;

- growth of the mutual importance of the markets of member states;

- establishing production communications;

- creation of new jobs in small and medium business.

9. Realization of the foreign trade potential:

- diversification of trade streams in the conditions of the accruing competition;

- reduction of transaction costs;

- conclusion of not preferential and preferential trade agreements;

- interaction in a dialogue format.

The purpose in the long term - creation of several common markets and spaces:

- the common market of energy resources (single market of gas and oil by 2025 , the common electrical power market by 2019 ;

- single transport space and development of the Eurasian transport corridors;

- the coordinated agro-industrial policy;

- elimination of barriers in the movement of goods and labor;

- formation of the common financial market of EEU.

In table 2, a consolidated list of economic spheres with the maximum integration potential of development for all EAEU member states was formed, based on the results of assessment of the sectoral priorities of cooperation of the EAEU member states up to 2030, conducted by Eurasian economic commission.

The list below shows in which spheres of the economy the maximum possible increase in economic results, an additional impulse to development through integration potential, expediency and priority of development of appropriate sectoral integration measures are expected by 2030 .

Within the EAEU the largest potential of development has:

1. In the sphere of goods - production of pharmaceutical production and goods of chemical industry. 
2. In a services sector - trips (covering goods and services purchased in a country during its visit by non-residents of that country for own consumption or subsequent transfer to a third party) and transport services.

Integration of the EAEU countries will provide the effect of «economy of scale» and will facilitate additional inflow of foreign direct investments (mutual and from the third countries). Proceeding from the practice of integration associations of the world, having a significant domestic market, it is economically profitable to develop and implement innovations, and also to implement infrastructure projects jointly, thus saving national resources and using each other's scientific and technological potential, or transferring technologies from developed countries for sharing. As for investments, they will be attractive primarily due to the bigger volume of the common domestic market and the opportunities for using the competitive advantages of member states. This will create a certain «safety margin» and strengthen the economic basis for the continuation of the integration dialogue, taking into account the possibility of expanding the membership of the EAEU member states in the long term.

Table 2 - The summary list of priority spheres of economy with the maximum integration potential of development for all member states of EAEU

\begin{tabular}{|c|c|c|c|}
\hline № & Integration effect & Goods/services & Spheres of economy \\
\hline \multirow[t]{2}{*}{1} & \multirow[t]{2}{*}{ Growth of mutual trade } & Goods & $\begin{array}{l}\text { Household chemicals; Black metals; Food; Pharmaceuticals; } \\
\text { Cosmetics; Furniture; Vehicles; Caoutchouc, rubber and products } \\
\text { from them; Light industry goods; Paints, varnishes }\end{array}$ \\
\hline & & Services & Transport services; trips \\
\hline \multirow[t]{2}{*}{2} & \multirow[t]{2}{*}{$\begin{array}{l}\text { Growth of non-oil and gas } \\
\text { export }\end{array}$} & Goods & $\begin{array}{l}\text { Production of electrical machines and } \\
\text { electric equipment; Production; Pharmaceutical production; } \\
\text { Crop production }\end{array}$ \\
\hline & & Services & Transport services; trips \\
\hline \multirow[t]{2}{*}{3} & \multirow[t]{2}{*}{ Import substitution } & Goods & $\begin{array}{l}\text { Metallurgical production from ferrous metals; Production of the basic } \\
\text { chemical elements; Production of pharmaceutical products; } \\
\text { Crop production }\end{array}$ \\
\hline & & Services & Construction services \\
\hline 4 & $\begin{array}{l}\text { Development of cooperation } \\
\text { communications }\end{array}$ & Goods & $\begin{array}{l}\text { Production of pharmaceutical products; Production of basic } \\
\text { chemicals; Production of non-ferrous metals }\end{array}$ \\
\hline
\end{tabular}

The economic spheres that provide a multiplicative effect for the economy of the EAEU (transport, energy, financial market, etc.), as well as the national economies of the member states, for which the scale of the market matters, have a great integration potential. Perspective cooperation is seen in the spheres that are not represented in the structure of the economies of the member states and have the prospects for long-term growth in the share in the domestic and foreign markets (to integrate into what isn't present, easier and more efficient than to compete for the division of established spheres of influence).

Global financial and economic crisis has accelerated regionalization process in North and South America, Southeast Asia, the Persian Gulf sub-region and the Arab-Muslim world, Australia and Oceania, the Western Africa. There are large regional systems with uniform algorithms of the interstate economical and financial relations.

In the XXI century, regional integration is becoming an important factor of counteraction to various global risks. In conditions of globalization, it is a fundamental issue of the economic and civilization development of states, of increase in their global competitiveness.

In the conditions of the crisis of modern monetarism and the institutions of its development, which is followed everywhere by series of destructive factors and the phenomena, an effective managing system of global processes is needed. The strategic initiatives of President Nursultan Nazarbayev to create a new model of the economy represent a system of productive proposals to the 
world community. This process is closely related to the prospects for Eurasian integration.

The current global instability is not only a crisis of the world economy, but also a crisis of international law and the entire political system of our time. This crisis is caused by the insecurity of the world payment unit - the US dollar. An exit for global capitalism will be either the bankruptcy of the emission center (which they do not want in the US, Britain, Switzerland and island off shores), or a new world war (to what the whole world is being pushed, especially to Russia and China).

Any attempts to reanimate the «sick» world economy by traditional methods obviously do not contribute to its recovery, since transnational capital is not inclined to change the rules. For example, the fundamental problems that led to the global financial and economic crisis of 2007-2009 have not been resolved.

The EAEU is considered as an integration core of the future Eurasian civilization, as a field that is open not only to the countries of the Eurasian continent, but also to the whole world. The Eurasian project, gradually realized as an international integration project, is aimed primarily at the formation of a fundamentally new integration model of cooperation between neighboring Eurasian countries.

In these conditions we observe various attempts to avoid a global crisis or, at least, to minimize its possible consequences (Arupov A.A., 2015).

In March 2014, restrictive political and economic measures (sanctions) were imposed on Russia and a number of Russian and Ukrainian individuals and organizations. According to some experts, sanctions have become one of the causes of the financial crisis in Russia. According to other experts, the causes of the crisis were not sanctions, but a decline in oil prices. The countries of the European Union have experienced a negative impact, both on their own sanctions and on Russia's response. The countries of the EAEU also felt the consequences of the economic and financial crisis in Russia. The exchange rate of the national currency in one union country greatly influences the economy of neighboring countries. Over the past year, representatives of the business of our countries suffered from the uncoordinated devaluation of national currencies.

The emerging transition from a unipolar to a multipolar system turns out to be much more dramatic and to some extent even tragic. A chapter of human history with unpredictable consequences and the many thousands victims is developed before our eyes. In particular, a year ago no one could have imagined that the bitter and bloody confrontation that covered
Libya, Afghanistan, Iraq, Syria, can be transferred from the Islamic world to the post-Soviet space, namely, to Ukraine (Abaidullayeva M.M., 2013)

Functioning of the Eurasian Economic Union is carried out in difficult external and internal political conditions. In the West, as it was already noted, this integration project was opposed by a number of influential politicians and experts. And in China, the attitude towards the Customs Union and the EAEU has recently changed for the better. The possibility of combining the project of the economic corridor of the Great Silk Road with the EAEU is being studied there.

The current problems of the development of the EAEU in the first year of its existence under the influence of external factors (delay of growth of the world economy, the Ukrainian crisis, the sanctions policy towards Russia, the sharp decline in world prices for oil and gas) once again emphasize the need to strengthen the interaction of the participating countries at the solution of the arising problems.

The work of the EAEU should be carried out gradually, without undue haste, taking into account and critical thinking about the experience of the formation and current problems of the European Union, which was recently perceived as the most successful example of a regional integration association. The current problems of the EU demonstrate inexpediency of accelerating the formation of a unified policy in the monetary and financial sphere due to the heterogeneity of the levels of development and structure of the economies of Russia, Kazakhstan, Belarus, Kyrgyzstan and Armenia. At the same time, economic expediency should not be sacrificed to political preferences, and the organization itself should become attractive to other countries, not only in the post-Soviet space Abaidullayeva M.M., Raitskaya L.K., Aroupova N.R, Vinokurov E., Tsukarev T., Gnidchenko A., Salnikov V. Golovnin M., Zakharov A., Ushkalova D. Sultanov B. K., Uralov S...

The main purpose of assessment of integration effects is to reduce the restrictions of long-term development of integration processes, including:

- improvement of trade relations;

- convergence of levels of technological development and restoration of cooperation communications;

- development of integration at the level of certain sectors of the economy.

The research of effects of economic integration is based on the theories which are marking out specific effects of trade integration for each participating country. Possible effects of trade integration of the countries of the Eurasian Economic Union are presented in table 3 . 
Table 3 - Effects of trade integration of the EAEU countries

\begin{tabular}{|l|l|l|}
\hline Conditions & Result & \multicolumn{2}{l|}{ Effects of trade integration } \\
\hline $\begin{array}{l}\text { Static effects } \\
\text { - the impact of integration on welfare of the integrating countries }\end{array}$ \\
\hline $\begin{array}{l}\text { - removal of barriers of mutual } \\
\text { trade between participants of } \\
\text { the agreement }\end{array}$ & - increase in volumes of foreign trade of the country & $\begin{array}{l}\text { - formation of new trade flows (trade } \\
\text { creation) }\end{array}$ \\
\hline $\begin{array}{l}\text { - reduction in cost of import } \\
\text { from the countries, included } \\
\text { into integration group }\end{array}$ & $\begin{array}{l}\text { - reorientation of trade flows to less effective products of } \\
\text { member countries of the trade agreement (in comparison } \\
\text { with third countries); } \\
\text { - a labor overflow from low-productive to high- } \\
\text { performance sectors of economy. }\end{array}$ & $\begin{array}{l}\text { - deviation of trade flows (trade } \\
\text { - effects in production, consumption, } \\
\text { employment, labor productivity and } \\
\text { incomes of the population. }\end{array}$ \\
\hline $\begin{array}{l}\text { - high level of an external } \\
\text { customs and tariff barrier }\end{array}$ & $\begin{array}{l}\text { - stimulation of development of the industrial sector } \\
\text { (theory of the training field) }\end{array}$ & $\begin{array}{l}\text { - industrialization based on import } \\
\text { substitution; } \\
\text { - insignificant structural changes due to } \\
\text { small regional markets. }\end{array}$ \\
\hline $\begin{array}{l}\text { Dynamic effects } \\
\text { - change of the basic conditions for the functioning of the economy }\end{array}$ & $\begin{array}{l}\text { - cost reduction, development of production } \\
\text { specialization; } \\
\text { - increase of competitiveness; } \\
\text { - stimulating the development of advanced technologies. }\end{array}$ & \begin{tabular}{l} 
scale effect \\
\hline
\end{tabular} \\
\hline $\begin{array}{l}\text { - reduction of costs; } \\
\text { - removal of barriers to the movement of capital } \\
\text { capital movements }\end{array}$ & \begin{tabular}{l} 
The effect of creating investment flows \\
\hline
\end{tabular} \\
\hline
\end{tabular}

The effectiveness of the integration of the EAEU countries depends, first of all, on the sustainable development of the participating countries, strengthening and deepening their economic relations. At the same time, not only the number, the territory, reserves of gas and oil, the total GDP of the countries, which is about $85 \%$ of GDP of all CIS countries, but also the geostrategic position and transit potential are the capacity of EAEU. (Raitskaya L.K., 2015).

Factors, both internal, and external character exert impact on achievement of a main objective of integration association of the countries, in particular:

- long terms of final formation of the common markets of the electric power, gas, oil and oil products (in some cases not earlier than 2025);

- lack of the arrangement on introduction of single currency policy;

- imperfection of a legal framework of EAEU;

- ineffectiveness of work of judicial instances in the consideration of disputes and conflicts between participants of business transactions;

- preservation of various restrictions for mutual trade in goods and services (when new member countries enter);

- unfavorable external economic conditions, worsening of the conjuncture in the world markets of raw materials and energy carriers;
- problems related to the crisis in Ukraine with observance of the mode of the unified customs territory of the EAEU countries, on trade and economic relations of Kazakhstan and Belarus with Ukraine; Russia;

- imposition of economic sanctions against

- decrease in rates of economic growth in Kazakhstan and Belarus;

- devaluation of national currencies;

- decrease in the standard of living of the population;

- growth of political instability and sharpening of social tension in the EAEU countries, etc.

Despite the existing difficulties, obstacles and negative moments in the first year of the existence of the EAEU, integration tendencies on the Eurasian space are still preserved, though in a weakened form.

Thus, the mutual trade of the EAEU states is only $13.5 \%$ of their total external trade turnover. The volume of mutual trade in goods for January-June 2016 amounted to 19 billion US dollars, or $83 \%$ to the level of January-June 2015.

The commodity structure of the mutual trade of the member states of the EAEU is characterized by the following indicators:

- the largest share is occupied by mineral products $-31.8 \%$ of the volume of mutual trade, of 
which $87.8 \%$ is supplied to the market of the EAEU by Russia;

- food products and agricultural raw materials $16.5 \%$ of the volume of mutual trade, of which $55.2 \%$ accounted for Belarus and 34.5\% - for Russia;

- cars, equipment and vehicles $-15.8 \%$ of the volume of mutual trade, $53.7 \%$ of which accounted for Russia and $43 \%$ - for Belarus;

- products of the chemical industry $-12.3 \%$ of the volume of mutual trade, $61.2 \%$ of them from Russia (Aroupova N.R, 2013).

The analysis of trade and economic relations of the countries of EAEU has allowed drawing a conclusion on need of development of effective model of trade, financial and investment interaction.

Obviously, the stability of the integration association is directly dependent on the economic component, i.e. from the positive economic effect that each country receives. Thus, in the Treaty on the Eurasian Economic Union, it was noted that to determine the degree of integration, the Eurasian Economic Commission should use such indicators as:

- a share of each state in the total amount of export of the member state (in \%);

- a share of each state in the total amount of import of the member state (in \%);

- a share of each member state in the total foreign trade turnover of the member state (in \%);

- the volume of the national investments directed to economy of each member state, including direct investments (in US dollar);

- the volume of investment, that has been received by the national economy from each member state, including direct investments (in US dollar).

On the basis of these indicators, it becomes possible to estimate the economic efficiency of integration processes in the EAEU Abaidullayeva M.M., Raitskaya L.K., Aroupova N.R, Vinokurov E., Tsukarev T., Gnidchenko A., Salnikov V. Golovnin M., Zakharov A., Ushkalova D. Sultanov B.K., Uralov S...

Economic effect for the EAEU member countries is distributed between its participants unevenly. Due to the short duration of the union, it is very difficult to accurately calculate the effects of integration for each country. At the same time, we can note the following. The system of distribution of revenues from import customs duties on the territory of the EAEU brings some dividends, in particular:

- increase in receipts from transit and cargo traffic through the territory of Kazakhstan by 4 times (January-June, 2015), in view of simplification of procedures of passing the customs border through Kazakhstan, low cost of automobile transportation of goods;
- establishment of consortium between Kazakhstan, Turkey, China, Azerbaijan and Georgia on transportation of freights from China to Europe (November, 2015). In the long term the creation of a transport and logistics hub is planned. At the same time Kyrgyzstan becomes the major regional transit state (large volumes of re-export trade flows pass through the largest markets of Central Asia "Dordoi" and "Karasuu");

- increase in the freight flow of agricultural goods, textile industry, etc.);

The main directions for achieving the maximum positive effect from the establishment of the EAEU by 2025 include the following:

1. Formation of uniform commodity market and services. This direction assumes "integration from below": growth of mutual trade, cross-border investments, civilized labor migration; creation of the single market of pharmaceutical and medicines (till January 1, 2016); the common electrical power market (by 2019); supranational financial institution of EAEU (by 2022); the single market of oil, gas and oil products (by 2025).

2. Unification and cancellation of non-tariff barriers in trade in goods and services. This direction assumes elimination of price control measures that affect competition (institute of special importers, restrictions on sales and government purchases, subsidies).

3. Effective coordination of macroeconomic and monetary policy which assumes annual state budget deficit no more than 3\% of GDP a national debt - no more than $50 \%$ of GDP, the rate of inflation - doesn't exceed $5 \%$. In addition to ensuring macroeconomic stability and the formation of unified principles for the functioning of the economy, the formation of unified rules for currency regulation and payment and settlement operations; coordination of monetary and fiscal policies; liberalization of banking sector services (participation of foreign capital, opening branches of foreign banks and removal of restrictions on the movement of capital); liberalization of access to the securities market, including free circulation of securities for national issuers and in respect of depositary activities are also necessary.

4. Creation of network of Free trade zones and agreements. This direction assumes signing of agreements of EAEU with Vietnam, Egypt, India, Israel, South Korea, Chile, South Africa, Iran and other countries in the field of development of trade in services, electronic trading, compliance of investment regime, technical regulation; activization of negotiation process between EAEU-EU and China ("The Economic belt of the Silk way"); liberalization 
of access to the financial markets, development of the international transport infrastructure, development of mechanisms of settlement of the trade conflicts, etc. (Vinokurov E., 2013).

Expected effects:

- an intensification of mutual trade due to decrease in transaction costs and volatility of exchange rates;

- development of the common financial market and investment flows;

- decrease in costs and risks;

- growth of volume of mutual investments;

- reduction of the prices of loan;

- decrease of the inflation rate and interest rates;

- economic stability;

- regional development;

- transport, power and financial interaction in Central Asia, Siberia and in the Far East.

etc.

An increase in long-term effects from a highquality change in interaction between countries and the development of integration processes in the EAEU is possible only with significant changes in the structure of production interactions connected with development of cooperation communications, alignment of technological level of production, harmonization of investment and financial policies.

\section{Conclusion}

Meanwhile, the leading countries of the EAEU do not have the necessary resources for realization of the financial and institutional development model, based on expanding demand and outrunning the leveling of parameters of the standard of living in the integration association.

The countries of the EAEU need their own agreed reindustrialization program, as further reduction of the contribution of manufacturing to GDP creates risks for macroeconomic stability and an increase in the qualitative component of economic dynamics.

Modernization of the production potential of the EAEU countries requires the development of specialized institutes focused on financing the projects in the production sector and their saturation with appropriate resources. For these purposes, the potential of financial institutions of development and the separate large companies, whose activity can have interstate character, can be involved.

\section{References}

Arupov A.A., Abaidullayeva M.M., Raitskaya L.K., Aroupova N.R. The Republic of Kazakhstan and the Russian Federation in the system of economic integration processes / under the scientific editorship of. prof. Arupov A.A. / - Almaty: Institute of World Economy and International Relations, Kazakhstan, 2015.- 120 p.

Decision of the Higher Eurasian Economic Council №28 "The main directions of Economic development of the EAEU until 2030", October 16, 2015 // The EEC Website. URL: http: //www.eurasiancommission. org / en / act / integr_i_makroec / dep_makroec_pol / seminar / Documents / brochure_ONER\% 20\% 28final\% 20 05.05.2016\% 29.pdf (reference date 28.05.2018

Vinokurov E., Tsukarev T. Economy of the EAEU: agenda // EEI. - 2015. - № 4 (29) November. - P.7-21

Gnidchenko A., Salnikov V. Evaluation of the effects and prospects of sectoral areas of integration of countries (on the example of Russia, Belarus and Kazakhstan). Report at the XV April International Scientific Conference of the National Research University "Higher School of Economics" on the problems of economic development and society.

Golovnin M., Zakharov A., Ushkalova D. Economic integration: lessons for the post-soviet space // World economy and international relations. - 2016.-V.60. - №4. - P. 62

Integration Policy of the Eurasian Economic Union / ed. prof. Arupov A.A / - Almaty: Institute of World Economy and International Relations, Kazakhstan, 2018. Publishing House "MIR".

International integration. Astana Economic Forum 2016 - New Opportunities for Growth // https://strategy2050.kz/en/news/35058/ (reference date 10.06.2018)

Long-term forecast of economic development of the Eurasian Economic Union until 2030 // Eurasian Economic Commission, Moscow, June 2015 - 215p.

On the prospects of Eurasian integration and a new model of the world economy // http: //group-global.org/en/news/o-perspektivah-evraziyskoy-integracii-inovoy-modeli-mirovoy-ekonomiki (reference date 10.06.2018)

Official site of the Eurasian Economic Commission / Official Statistical Information of the Unified Energy System of Ukraine // http://www.eurasiancommission.org/en/act/integr_i_makroec/dep_stat/union_stat/Pages/default.aspx (reference date 29.05.2018)

Sultanov B. K. Eurasian project and modern global challenges // International Likhachev scientific readings / Modern global challenges and national interests: XV International Likhachev Scientific Readings, May 14-15, 2015 - St. Petersburg: SPbGUP, 2015.-C. 466-469

Treaty on the Eurasian Economic Union / / Ministry of Economic Development of the Russian Federation. Official website. Access mode: http://economy.gov.ru/minec/about/structure/depSNG/agreement-eurasian-economic-union (reference date 29.05.2018)

The Eurasian Economic Union: from idea to realization (to the 20th anniversary of the speech of the President of the Republic of Kazakhstan Nazarbayev N.A. in the Moscow State University named after Lomonosov M.V.). Materials of the international conference 
(Almaty, March 18, 2014) / under the editorship of Sultanov B.K. - Almaty: KISI under the President of the Republic of Kazakhstan, 2014. - 160 p.-P.45

The Eurasian doctrine of Nursultan Nazarbayev / compilers: Nysanbayev A.N., Dunaev V.Yu. - Almaty, 2010. - P.13.

From the idea of the Eurasian Union to new perspectives of Eurasian integration // http: //eurasianclub.ru/ot-idei-evrazijskogosoyuza-k-novym-perspektivam-evrazijskoj-integrac/ (reference date 28.05.2018)

Uralov S. Global challenges of Eurasian integration and strategic tasks for the Republic of Armenia. Report at the international conference "Regions of Armenia for Eurasian Integration", Kapan, June 5, 2014 // http://www.soyuzinfo.am/eng/analitics/detail. php?ELEMENT_ID=1139 (reference date 29.05.2018) 